\title{
KEBEBASAN BERPENDAPAT TERHADAP PEMERINTAH MELALUI MEDIA SOSIAL DALAM PERSPEKTIF UU ITE
}

\author{
Nur Rahmawati, Muslichatun, M. Marizal \\ Fakultas Ilmu Sosial dan Ilmu Politik Universitas Tidar \\ J1. Kapten Suparman 39 Potrobangsan, Magelang Utara, Jawa Tengah, 56116 \\ nurrahmawati1806@gmail.com
}

\begin{abstract}
Abstrak
Pemerintah menuntut keaktifan masyarakat dalam mengkritik pemerintah. Namun, pernyataan tersebut menimbulkan polemik berbagai kalangan. Tujuan penulisan ini ialah untuk mengetahui respons mahasiswa terkait pemerintah yang menuntut untuk dikritik, namun terancam oleh UU ITE. Dan membahas bentuk jaminan hukum agar masyarakat dalam mengkritik pemerintah dapat terlindung dari sanksi pidana. Penelitian ini menggunakan metode penelitian kuantitatif, dengan melakukan survei melalui kuesioner, dan metode yuridis normatif yaitu menganalisis permasalahan berdasarkan peraturan perundang-undangan dan literatur hukum. Adanya UU ITE membuat masyarakat khawatir dalam memberi kritik dan masukan kepada pemerintah karena kurangnya jaminan atas kebebasan berpendapat dalam memberikan kritikan kepada pemerintah melalui media sosial.
\end{abstract}

Kata Kunci: Kebebasan Berpendapat, Pemerintah, Media Sosial, dan UU ITE.

\begin{abstract}
The government demands public activeness in criticizing the government. However, this statement caused polemic in various circles. The purpose of this paper is to determine the student's response to the government who demands to be criticized, but is threatened by the ITE Law. And discussing forms of legal guarantees so that people in criticizing the government can be protected from criminal sanctions. This research uses quantitative research methods, by conducting surveys through questionnaires, and normative juridical methods, namely analyzing problems based on statutory regulations and legal literature. The existence of the ITE Law makes the public worry about giving criticism and input to the government because of the lack of guarantees for freedom of opinion in criticizing the government through social media.
\end{abstract}

Keywords: Freedom of Opinion, Government, Social Media, dan The ITE Law.

\section{A. Pendahuluan}

Dewasa ini, perkembangan teknologi informasi dan komunikasi menjadi semakin pesat serta tebukti sudah memberikan kemanfaatan bagi para penggunanya. Setiap individu dapat mengakses infomasi hanya dengan ponsel atau alat komunikasi lain yang terkoneksi dengan internet. Masyarakat yang berasal dari berbagai usia dan berbagai golongan dapat dengan mudah mengakses internet sebagai sarana komunikasi dan berbagi informasi tanpa batasan waktu, salah satu medianya ialah melalui media sosial.

Dilihat dari satu sisi, adanya media sosial dapat memberikan manfaat bagi kesejahteraan masyarakat. Seluruh lapisan masyarakat dapat mengakses media sosial untuk mengekspresikan diri, salah satunya dengan berpendapat dalam bentuk kritik terhadap pemerintah. Tiap individu memiliki kebebasan untuk berpendapat, di mana itu merupakan hak asasi yang melekat pada setiap manusia yang termaktub dalam Pasal 23 ayat (2) UndangUndang Nomor 39 Tahun 1999 tentang Hak Asasi Manusia. Dengan adanya dasar hukum mengenai kebebasan berpendapat tersebut, masyarakat beranggapan untuk bebas 
mengeluarkan pikiran dan gagasannya, salah satunya dengan melakukan kritik terhadap pemerintah. Akan tetapi, dalam prakteknya, banyak timbul permasalahan terkait dengan penyampaian kritik oleh masyarakat terhadap pemerintah melalui media sosial tersebut.

Indonesia merupakan Negara hukum dimana setiap tindakan warga negaranya diatur secara yuridis dalam peraturan perundang-undangan, begitu pula dengan pengaturan mengenai etika penyampaian kritik melalui media sosial. Instrumen hukum yang mengatur dalam bidang teknologi informasi, terutama berkaitan dengan etika dalam penyampaian kritik yaitu diatur dalam Undang-Undang tentang Informasi dan Transaksi

Elektronik. UU No. 19 Tahun 2016 tentang Perubahan Atas UU No. 11 Tahun 2008 tentang Informasi dan Transaksi Elektronik mengatur mengenai penegakan hukum terhadap pelanggaran dalam penggunaan teknologi informasi, salah satunya bagi individu yang menggunakan media teknologi infomasi seperti media sosial sebagai media penyampaian kritik terhadap pemerintah. Ketentuan yang mengatur terkait hal tersebut antara lain, Pasal 27 ayat (3), Pasal 28 ayat (2), Pasal 45A ayat (2), Pasal 45 ayat (3) UU 19/2016 tentang UU ITE.

Sosial media dalam hal ini secara tidak langsung memberikan kebebasan kepada masyarakat untuk bebas berpendapat, namun di sisi lain juga menjadi ancaman bagi pengguna karena terdapat aturan dalam UU ITE yang dianggap mengintai serta membatasi kebebasan berpendapat tersebut.

Tidak sedikit orang yang telah dipidana karena dianggap telah mencemarkan nama baik dan diancam dengan UU ITE, salah satunya kasus yang menimpa seorang penulis kolom berita surat kabar bernama Bersihar Lubis. Kasus tersebut bermula dari tulisannya yang dipublikasi dalam harian Koran Tempo pada 17 Maret 2007 yang berjudul "Kisah Interogator yang Dungu", dimana dalam tulisan tersebut Bersihar melakukan kritik terhadap pelarangan buku sejarah oleh Kejaksaan Agung. Tulisan Bersihar tersebut mengakibatkan staff Kejaksaan Negeri Depok merasa tersinggung. Bersihar dituntut ke pengadilan karena tulisannya yang berisikan kritikan tersebut dianggap menghina Kejaksaan Agung yang mengakibatkan Bersihar terancam hukuman delapan bulan penjara. Kasus-kasus yang dianggap berisi pengekangan terhadap kebebasan berpendapat ini menimbulkan sebagian masyarakat merasa was-was dalam melakukan kritik terhadap pemerintah, sedangkan sebagian masyarakat lain memutuskan untuk tidak beropini melalui kritik terhadap pemerintah atas kondisi sosial politik dalam pemerintahan. 
Negara Indonesia adalah Negara demokrasi, salah satu karakteristiknya ditandai dengan adanya jaminan perlindungan kebebasan berpendapat, sehingga dalam hal ini pemerintah dan lembaga yang bersangkutan sudah seharusnya berupaya dalam usaha penghormatan terhadap kebebasan berpendapat ini. Sebuah Negara dianggap benar-benar demokratis, ia harus siap memberikan perlindungan substansial untuk ide-ide pengeluaran pendapat media. ${ }^{1}$ UU ITE sebelum direvisi maupun setelah direvisi, memang seringkali menimbulkan kontroversi terkait pasal-pasal tertentu. Meskipun demikian, UU ITE ini penting jika melihat jumlah pengguna internet di Indonesia yang cukup besar dan kian masa kian meningkat. Untuk meminimalisasi dampak negatif tentu saja perlu adanya batasan untuk menjamin kenyamanaan dan perlindungan warga penggunanya. Berkaitan dengan problematika tersebut, dirasa sangat menarik untuk dikaji dalam sebuah artikel yang berjudul "Kebebasan Berpendapat Terhadap Pemerintah Melalui Media Sosial Dalam Perspektif UU ITE”.

Penulis merumuskan ke dalam dua permasalahan, yang pertama membahas mengenai respons mahasiswa terkait pemerintah yang menuntut dikritik namun UU ITE mengancam. Kemudian, yang kedua ialah mengenai bentuk jaminan pemerintah terkait masyarakat yang memberikan kritik agar terhindar dari sanksi pidana.

Tujuan dari penulisan artikel ini adalah untuk mengetahui respons mahasiswa terkait pemerintah yang menuntut untuk dikritik, tetapi terancam oleh UU ITE. Lebih lanjut penelitian ini juga bertujuan untuk mengetahui sejauh mana pemahaman mahasiswa mengenai UU ITE. Tujuan yang kedua adalah untuk mengulas dan memberikan informasi bagi pembaca mengenai bentuk jaminan pemerintah terkait masyarakat yang memberikan kritikan supaya terlindung dari sanksi pidana.

\section{B. Telaah Konsep}

\section{Kebebasan Berpendapat}

Secara umum istilah kebebasan biasanya dikaitkan dengan tiadanya penghalang, pembatas, ikatan, paksaan, hambatan, kewajiban dari hal tertentu atau untuk melakukan sesuatu. ${ }^{2}$ Hak dalam kebebasan berpendapat adalah bagian dari hak asasi setiap manusia. Manusia dilahirkan dengan dikaruniai sesuatu yang tidak seharusnya diusik oleh pihak manapun. Tercantum dalam Pasal 1 Undang-Undang Nomor 39 Tahun 1999 tentang HAM

1 John W, Johnson. "Peran Media Bebas". Office of International Information Program U.S Department of State NO. 7 Maret 2001

${ }^{2}$ Sartini. 2008. Etika Kebebasan Beragama. Jurnal Filsafat. Vol 18 No 3. Hal. 242-243. 
disebutkan bahwa "Hak Asasi Manusia adalah seperangkat hak yang melekat pada hakekat dan keberadaan manusia sebagai makhluk Tuhan Yang Maha Esa dan merupakan anugerahNya yang wajib dihormati, dijunjung tinggi dan dilindungi oleh negara, hukum, pemerintah, dan setiap orang demi kehormatan serta perlindungan harkat dan martabat manusia".

Kebebasan berpendapat merupakan hak asasi manusia yang sangat fundamental. Indonesia secara tegas mencantumkan penghargaan kebebasan berpendapat dalam UndangUndang Dasar Tahun 1945 (UUD 1945) serta telah memperoleh pengakuan secara internasional melalui Deklarasi Universal HAM (DUHAM) tahun 1948.

\section{Pengertian Media Sosial}

Media Sosial adalah interaksi sosial antara manusia dalam memproduksi, berbagi dan bertukar informasi, hal ini mencakup gagasan dan berbagai konten dalam komunitas virtual (Ahlqvist dkk ,2008 dalam Sulianta, Feri 2015). Media sosial adalah wadah bagi setiap orang dalam membuat web page pribadi dan terhubung dengan khalayak umum sesama pengguna media sosial untuk berkomunikasi, saling bertukar informasi, dan dapat pula menjadi media dalam menuangkan gagasan dan pendapat. Beberapa platform media sosial antara lain facebook, twitter, dan instagram. Media sosial merupakan media online yang tentunya berbeda dengan media tradisional dalam bentuk media cetak. Media sosial ini menggunakan jaringan internet yang melibatkan partisipasi banyak orang untuk memberikan feedback dari sebuah informasi, memberi komentar, membagikan informasi, serta menciptakan gagasan dan kritik di mana semua hal tersebut dilakukan tanpa terbatas tempat dan waktu.

\section{Pengertian Undang-Undang}

Pengertian dari peraturan perundang-undangan diatur dalam Pasal 1 angka 2 UU No. 12 Tahun 2011 tentang Pembentukan Peraturan Perundang-Undangan (UU 12/2011) adalah peraturan tertulis yang memuat norma hukum yang mengikat secara umum dan dibentuk atau ditetapkan oleh lembaga negara atau pejabat yang berwenang melalui prosedur yang ditetapkan dalam Peraturan Perundang-undangan. Secara yuridis atau dalam perspektif hukum, undang-undang dapat memiliki dua makna: ${ }^{4}$

a) Undang-undang secara formil adalah setiap bentuk peraturan perundangan yang diciptakan oleh lembaga yang kompeten dalam pembuatan undang-undang yaitu Dewan Perwakilan Rakyat dan Presiden sebagai kepala pemerintahan atau setiap

${ }^{3}$ Undang-Undang Nomor 39 Tahun 1999 tentang Hak Asasi Manusia.

${ }^{4}$ Yulies Tiena Masriani, Pengantar Hukum Indonesia (Cet. XII; Jakarta: Sinar Grafika,2017),hal 14. 
keputusan tertulis sebagai hasil kerja sama antara pemegang kekuasaan eksekutif dan legislatif yang berisi aturan tingkah laku yang mengikat secara umum. Salah satu contohnya adalah Undang-Undang Nomor 11 Tahun 2008 tentang Informasi dan Transaksi Elektronik (ITE).

b) Undang-undang secara materil adalah setiap produk hukum yang memiliki fungsi regulasi (pengaturan), yang bersumberkan seluruh dimensi kehidupan manusia, ekonomi, politik, sosial budaya, kesehatan, agama, dan dimensi kehidupan lainnya atau setiap keputusan tertulis yang dikeluarkan pejabat berwenang yang berisi aturan tingkah laku yang bersifat atau mengikat secara umum. Bentuknya bisa bertingkat, mulai dari Undang-Undang Dasar sampai ke peraturan tingkat desa. Contoh produk hukum yang dibuat oleh semua lembaga yang memiliki kompetensi membuat peraturan perundangan, seperti UU, Peraturan Pemerintah, Keputusan Presiden,dan Peraturan Daerah. ${ }^{5}$

\section{Pengertian Informasi dan Transaksi Elektronik (ITE)}

Dalam Pasal 1 angka 1 UU No. 14 Tahun 2008 tentang Keterbukaan Informasi Publik, 'informasi' adalah keterangan, pernyataan, gagasan, dan tanda-tanda yang mengandung nilai, makna, dan pesan, baik kata, fakta, maupun penjelasan yang dapat dilihat, didengar, dan dibaca yang disajikan dalam berbagai kemasan dan format sesuai dengan perkembangan teknologi dan komunikasi secara elektronik maupun nonelektronik. $^{6}$

Berdasarkan Undang-Undang Nomor 19 Tahun 2016 atas perubahan Undang-undang No 11 Tahun 2008Tentang Informasi dan Transaksi Elektronikbahwa Informasi elektronik adalah satu atau sekumpulan data elektronik yang tidak terbatas pada tulisan, suara, gambar, peta, rancangan, foto, electronic data interchange (EDI), surat elektronik (electronic mail), telegram, atau sejenisnya, huruf, tanda, angka, kode akses, simbol, atau perforasi yang telah diolah yang memiliki arti atau dapat dipahami oleh orang yang mampu memahaminya. Sedangkan, Transaksi Elektronik adalah perbuatan hukum yang dilakukan dengan menggunakan Komputer, jaringan Komputer, dan/atau media elektronik lainnya. Adapun UU ITE adalah undang-undang yang mengatur tentang informasi serta transaksi elektronik, atau teknologi informasi secara umum. UU ini memiliki yuridiksi yang berlaku untuk setiap orang yang

${ }^{5}$ Ilhami Bisri, Sistem Hukum Indonesia (Cet. II; Jakarta: PT Raja Grafindo Persada,2005), hal 36.

${ }^{6}$ UU No. 14 Tahun 2008 tentang Keterbukaan Informasi Publik. 
melakukan perbuatan hukum sebagaimana diatur dalam undang-undang ini, baik yang berada di wilayah hukum Indonesia, maupun diluar wilayah hukum Indonesia, yang memiliki akibat hukum di wilayah hukum Indonesia dan/atau di luar wilayah hukum Indonesia dan merugikan kepentingan Indonesia. ${ }^{7}$

\section{Metode Penelitian}

Terdapat dua jenis metode penelitian yang diterapkan dalam penulisan artikel ini, yang pertama adalah dengan menggunakan metode penelitian kuantitatif, dengan melakukan survei melalui kuesioner. Penelitian kuantitatf dilakukan dengan analisis statistik berupa persentase dalam bentuk angka. Sedangkan dalam mengalisis data menggunakan statistik deskriptif. Statistik deskriptif digunakan untuk mengalisis data dengan cara mendeskripsikan atau menggambarkan data yang telah terkumpul sebagaimana adanya tanpa bermaksud membuat membuat kesimpulan yang berlaku untuk umum atau generalisasi. ${ }^{8}$

Kemudian metode penelitian yang kedua adalah melalui metode yuridis normatif yang mana dilakukan dengan menganalisis permasalahan dengan berdasarkan pada peraturan perundang-undangan dan literatur-literatur yang meliputi buku, makalah maupun artikel berkaitan dengan pokok permasalahan yang menjadi pembahasan ini yaitu mengenai UU ITE. Penelitian ini merupakan penelitian kepustakaan yang dilakukan dengan pengumpulan bahan hukum melalui studi kepustakaan dengan berpedoman pada bahan hukum primer dan bahan hukum sekunder. Bahan hukum primer meliputi peraturan perundang-undangan yaitu Undang-Undang Nomor 39 Tahun 1999 tentang Hak Asasi Manusia serta Undang-Undang Nomor 19 Tahun 2016 tentang Undang-Undang Informasi dan Transaksi Elektronik., sedangkan bahan hukum sekunder meliputi literatur hukum di luar peraturan perundangundangan yaitu buku dan jurnal dalam bidang UU ITE.

\section{Pembahasan}

Analisis Mengenai Respons Mahasiswa terkait Pemerintah yang Menuntut Dikritik tetapi UU ITE Mengancam

\footnotetext{
${ }^{7}$ Undang-Undang Nomor 19 Tahun 2016 atas perubahan Undang-undang No 11 Tahun 2008Tentang Informasi dan Transaksi Elektronik.

${ }^{8}$ Sugiyono, Metode Penelitian Kuantitatif Kualitatif dan R\&D, (Bandung: ALFABETA, 2008), hal. 147.
} 
Berdasarkan penelitian yang dilakukan terhadap mahasiswa Universitas Tidar dengan 110 responden. Penelitian ini dilakukan dalam jangka waktu satu minggu dengan menggunakan metode penelitian quota sampling, yaitu dengan cara membagikan kuesioner kepada mahasiswa melalui Google Docs (Google Formulir). Kuesioner tersebut terdiri atas tujuh pertanyaan tertutup. Hasilnya sebagai berikut:

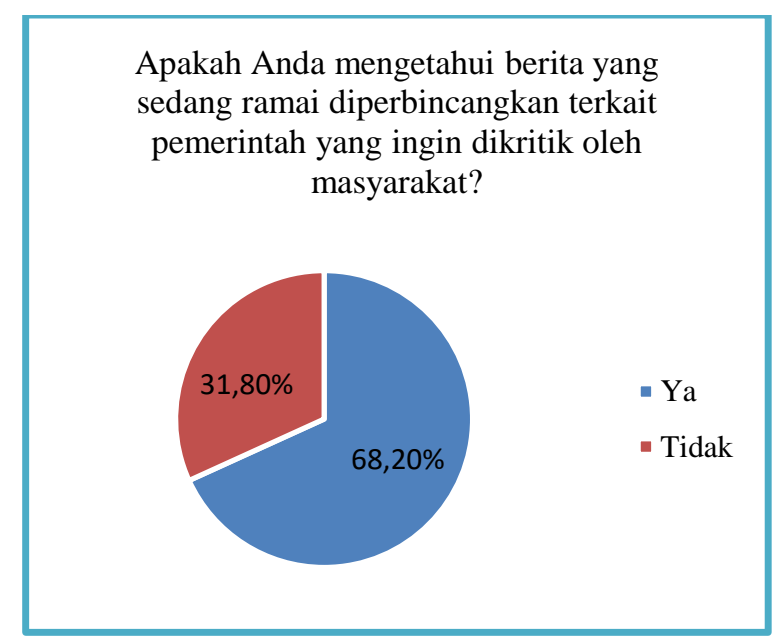

Gambar 1. Pengetahuan mahasiswa mengenai berita yang sedang ramai diperbincangkan terkait pemerintah yang ingin dikritik oleh masyarakat

Berdasarkan diagram di atas, maka mahasiswa yang mengetahui berita yang sedang ramai diperbincangkan terkait pemerintah yang ingin dikritik oleh masyarakat sebanyak 75 responden dan 35 responden tidak mengetahuinya.

Berita mengenai pemerintah yang ingin dikritik oleh masyarakat memang sedang ramai diperbincangkan. Kritik tersebut digunakan pemerintah untuk meningkatkan kinerja pemerintah dalam rangka memperbaiki pelayanan publik kepada masyarakat, terutama dalam penanganan pandemi Covid-19 saat ini. Masukan dan kritikan masyarakat sangat penting karena merupakan wujud dari demokrasi suatu negara. Akan tetapi, pernyataan pemerintah tersebut menuai polemik berbagai kalangan. 


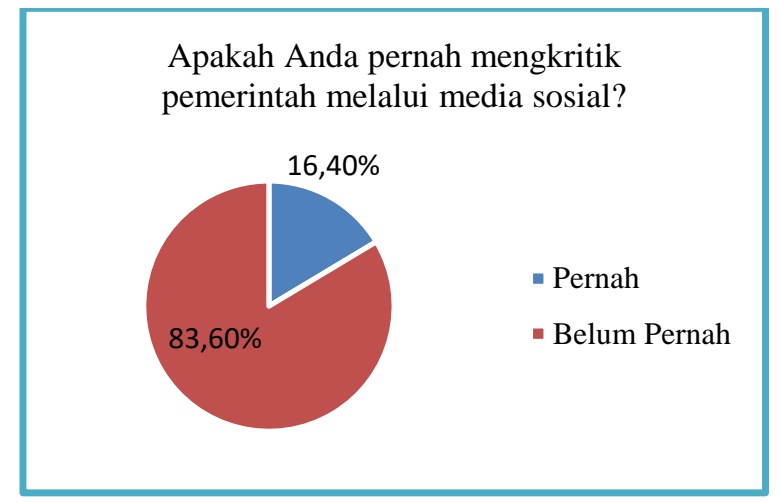

Gambar 2. Pernah tidaknya mahasiswa mengkritik pemerintah melalui media sosial

Berdasakan diagram di atas, maka mahasiswa yang tidak pernah mengkritik pemerintah melalui media sosial sebanyak 18 responden dan 92 responden pernah mengkritik pemerintah melalui media sosial.

Dari data di atas, masih banyak mahasiswa yang belum pernah mengkritik pemerintah melalui media sosial. Hal ini disebabkan berbagai faktor yang mempengaruhinya. Salah satunya terdapat sanksi pidana jika dalam menyampaikan pendapat melanggar peraturan perundang-perundangan yang berlaku.

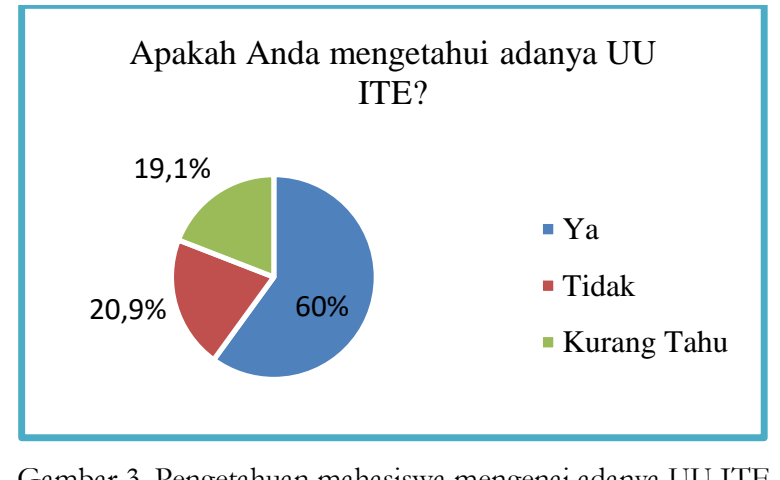

Gambar 3. Pengetahuan mahasiswa mengenai adanya UU ITE

Berdasakan diagram di atas, maka mahasiswa yang mengetahui adanya UU ITE sebanyak 66 responden, dan yang tidak mengetahui adanya UU ITE 23 responden, serta yang kurang tahu adanya UU ITE 21 responden.

Undang-Undang Informasi dan Transaksi Elektronik (UU ITE) merupakan salah satu peraturan yang mengatur tentang kebebasan berpendapat melalui media sosial. Jika berdasarkan data di atas, maka sudah banyak yang mengetahui tentang adanya UU ITE. Akan tetapi, ternyata masih ada mahasiswa yang tidak mengetahui adanya UU ITE bahkan terdapat responden yang kurang tahu mengenai adanya UU ITE tersebut. 


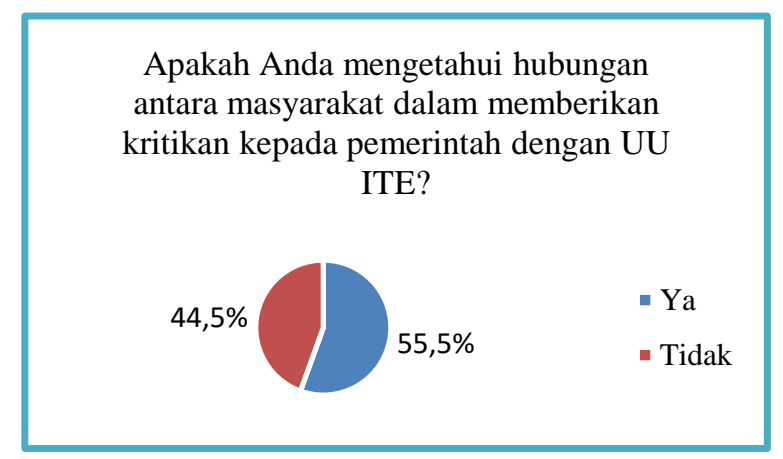

Gambar 4. Pengetahuan mahasiswa mengenai hubungan antara masyarakat dalam memberikan kritikan kepada pemerintah dengan UU ITE

Berdasakan diagram di atas, maka mahasiswa yang mengetahui hubungan antara masyarakat dalam memberikan kritikan kepada pemerintah dengan UU ITE sebanyak 61 responden dan 49 responden tidak mengetahui hubungan antara masyarakat dalam memberikan kritikan kepada pemerintah dengan UU ITE.

Hubungan antara masyarakat dalam memberikan kritikan kepada pemerintah dengan UU ITE yaitu UU ITE merupakan salah satu regulasi yang mengatur tentang kebebasan berpendapat melalui media sosisal. Itulah yang menyebabkan masyarakat merasa takut jika mengkritik pemerintah melalui media sosial yang akan dikenakan sanksi pidana jika dianggap melanggar UU ITE. Karena sebagian masyarakat menganggap pasal-pasal dalam UU ITE itu masih multitafsir sehingga menyebabkan

masyarakat menjadi takut jika ingin mengkritik pemerintah melalui media sosial.

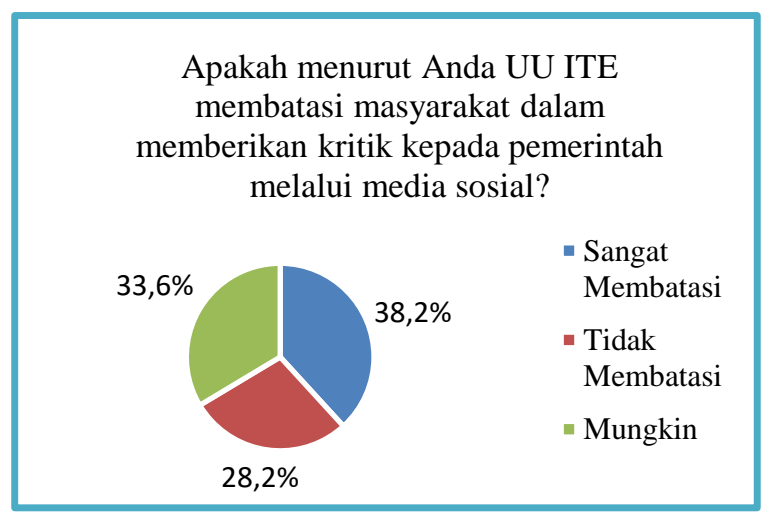

Gambar 5. Pendapat mahasiswa mengenai UU ITE yang dianggap membatasi masyarakat dalam memberikan kritik kepada pemerintah melalui media sosial

Berdasakan diagram di atas, maka mahasiswa yang menganggap UU ITE membatasi masyarakat dalam memberikan kritik kepada pemerintah melalui media sosial sebanyak 42 responden, dan 31 responden menganggap UU ITE tidak membatasi masyarakat dalam memberikan kritik kepada pemerintah melalui media sosial, serta 37 responden menganggap UU ITE mungkin membatasi masyarakat dalam memberikan kritik kepada pemerintah melalui media sosial. 
Jika berdasarkan data di atas, maka masyarakat menganggap UU ITE itu sangat membatasi ketika masyarakat ingin memberikan kritikan kepada pemerintah melalui media sosial. Masyarakat menganggap di dalam UU ITE itu masih terdapat pasal-pasal karet yang dapat menjerat masyarakat kapan saja.

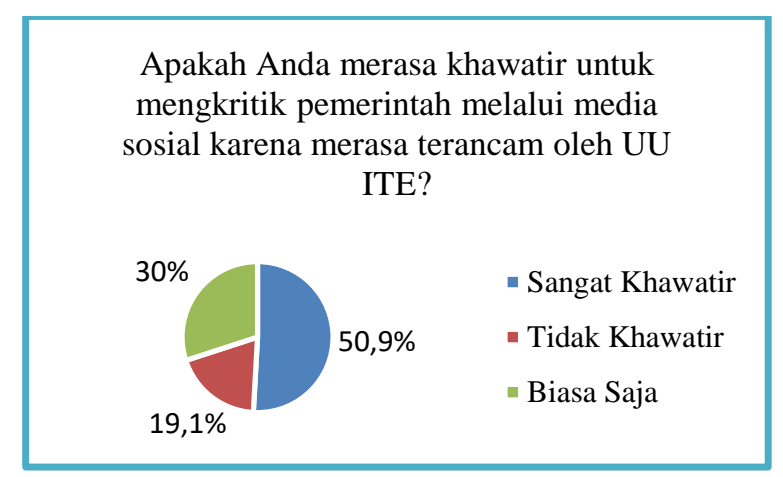

Gambar 6. Pendapat mahasiswa mengenai kekhawatiran dalam mengkritik pemerintah melalui media sosial karena adanya UU ITE

Berdasakan diagram di atas, maka mahasiswa yang merasa khawatir untuk mengkritik pemerintah melalui media sosial karena merasa terancam oleh UU ITE sebanyak 56 responden, dan 21 responden merasa tidak khawatir untuk mengkritik pemerintah melalui media sosial karena merasa terancam oleh UU ITE, serta 33 responden merasa biasa saja untuk mengkritik pemerintah melalui media sosial karena merasa terancam oleh UU ITE.

Jika dilihat berdasarkan data di atas, maka masih banyak mahasiswa yang merasa khawatir untuk mengkritik pemerintah melalui media sosial karena merasa terancam oleh UU ITE. Kekhawatiran itu yang menimbulkan pro kontra berbagai kalangan ketika pemerintah ingin masyarakat lebih aktif lagi dalam memberikan masukan dan kritikan kepada pemerintah.

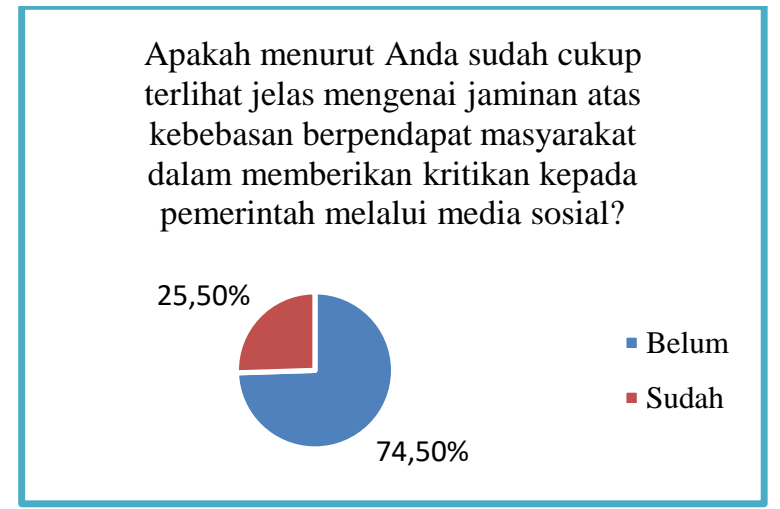

Gambar 7. Pendapat mahasiswa mengenai jaminan atas kebebasan berpendapat masyarakat dalam memberikan kritikan kepada pemerintah melalui media sosial 
Berdasakan diagram di atas, maka mahasiswa yang menganggap belumh cukup terlihat jelas mengenai jaminan atas kebebasan berpendapat masyarakat dalam memberikan kritikan kepada pemerintah melalui media sosial sebanyak 82 responden dan 28 responden menganggap sudah cukup terlihat jelas mengenai jaminan atas kebebasan berpendapat masyarakat dalam memberikan kritikan kepada pemerintah melalui media sosial.

Jika melihat data di atas, maka pasal-pasal di dalam UU ITE itu dianggap belum cukup terlihat jelas mengenai jaminan atas kebebasan berpendapat masyarakat dalam memberikan kritikan kepada pemerintah melalui media sosial. Hal inilah yang menyebabkan masyarakat merasa khawatir dan takut dalam memberikan kritikan kepada pemerintah melalui media sosial.

Akhir-akhir ini sedang ramai mengenai berita yang memperbincangkan terkait pemerintah yang ingin dikritik oleh masyarakat. Pemerintah menuntut masyarakat lebih aktif lagi dalam memberikan kritik kepada pemerintah dalam rangka meningkatkan kinerja dan memperbaiki pelayanan publik kepada masyarakat. Namun, pernyataan tersebut menimbulkan polemik berbagai kalangan. Hal ini dikarenakan adanya beberapa regulasi yang dianggap membatasi masyarakat dalam

memberikan masukan dan kritikan, terutama Undang-Undang Nomor 19 Tahun 2016 tentang Perubahan Atas Undang-Undang Nomor 11 Tahun 2008 tentang Informasi dan Transaksi Elektronik (UU ITE). UU ITE ini membuat masyarakat menjadi khawatir jika ingin memberikan masukan dan kritikan kepada pemerintah.

Selain itu, UU ITE dianggap belum memberikan jaminan atas kebebasan berpendapat masyarakat dalam memberikan kritikan kepada pemerintah melalui media sosial. Karena di dalam UU ITE tersebut masih terdapat pasal-pasal karet yang menimbulkan multitafsir berbagai kalangan. Itulah hubungan antara masyarakat dalam memberikan kritikan kepada pemerintah dengan UU ITE.

\section{Bentuk Jaminan Pemerintah terkait Masyarakat yang Memberikan Kritik agar Terhindar dari Sanksi Pidana}

Dalam meningkatkan pembangunan dalam rangka perbaikan pelayanan publik yang lebih baik lagi, maka pemerintah Indonesia memerlukan peran partisipasi aktif dari masyarakat untuk menyampaikan masukan dan kritikan kepada pemerintah. Dengan adanya masukan dan kritikan dari masyarakat, pemerintah dapat meningkatkan lagi kinerjanya, terutama dalam penanganan pandemi saaat ini. 
Pernyataan pemerintah tersebut, menuai pro kontra berbagai kalangan. Hal ini dikarenakan adanya beberapa regulasi yang dianggap membatasi masyarakat dalam menyampaikan pendapatnya, terutama Undang-Undang Nomor 19 Tahun 2016 tentang Perubahan Atas Undang-Undang Nomor 11 Tahun 2008 tentang Informasi dan Transaksi Elektronik (UU ITE). Di dalam undang-undang tersebut, terdapat pasal-

pasal yang dianggap dapat mengancam masyarakat ketika memberi kritikan kepada pemerintah.

Adapun yang paling berpotensi jadi pasal karet, yaitu pasal 27 ayat 1 tentang asusila, pasal 27 ayat 3 tentan pencemaran, dan pasal 28 ayat 2 tantang ujaran kebencian. ${ }^{9}$ Pasal 27 ayat (1) Undang-Undang Nomor 11 Tahun 2008 tentang Informasi dan Transaksi Elektronik yang berbunyi, "Setiap Orang dengan sengaja dan tanpa hak mendistribusikan dan/atau mentransmisikan dan/atau membuat dapat diaksesnya Informasi Elektronik dan/atau Dokumen Elektronik yang memiliki muatan yang melanggar kesusilaan”. Sedangkan Pasal 27 ayat (3) Undang-Undang Nomor 11 Tahun 2008 tentang Informasi dan Transaksi Elektronik menegaskan bahwa, "Setiap Orang dengan sengaja dan tanpa hak mendistribusikan dan/atau mentransmisikan dan/atau membuat dapat diaksesnya Informasi Elektronik dan/atau Dokumen Elektronik yang memiliki muatan penghinaan dan/atau pencemaran nama baik". Dan Pasal 28 ayat (2) Undang-Undang Nomor 11 Tahun 2008 tentang Informasi dan Transaksi Elektronik menjelaskan bahwa, "Setiap Orang dengan sengaja dan tanpa hak menyebarkan informasi yang ditujukan untuk menimbulkan rasa kebencian atau permusuhan individu dan/atau kelompok masyarakat tertentu berdasarkan atas suku, agama, ras, dan antargolongan (SARA)". Pasal-pasal tersebut dianggap membatasi masyarakat dalam memberikan masukan dan kritikan kepada pemerintah. UU ITE ini dianggap beberapa pihak sering digunakan untuk menjerat pihak yang telah mengkritik pemerintah. Masyarakat meminta kepada pemerintah agar dilakukan revisi terhadap UU ITE tersebut. Tujuannya agar masyarakat mendapatkan jaminan perlindungan dan terbebas dari sanksi pidana ketika memberikan masukan dan kritikan kepada pemerintah sehingga dapat mewujudkan negara yang demokrasi.

\section{E. Penutup}

${ }^{9}$ Rosy Dewi Arianti Saptoyo. Jokowi Minta Masyarakat Aktif Beri Kritik, Warganet: Lalu Kena UU ITE, https://www.kompas.com/tren/read/2021/02/09/160000565/jokowi-minta-masyarakat-aktif-berikritik-warganet-lalu-kena-uu-ite?page=all, (Diakses pada tanggal 27 Februari 2021 pukul 12.12 WIB). 
Akhir-akhir ini sedang ramai mengenai berita yang memperbincangkan terkait pemerintah yang ingin dikritik oleh masyarakat. Pemerintah menuntut masyarakat lebih aktif lagi dalam memberikan kritik kepada pemerintah dalam rangka meningkatkan kinerja dan memperbaiki pelayanan publik kepada masyarakat. Namun, pernyataan tersebut menimbulkan polemik berbagai kalangan. Hal ini dikarenakan adanya beberapa regulasi yang dianggap membatasi masyarakat dalam memberikan masukan dan kritikan, terutama Undang-Undang Nomor 19 Tahun 2016 tentang Perubahan Atas Undang-Undang Nomor 11 Tahun 2008 tentang Informasi dan Transaksi Elektronik (UU ITE). UU ITE ini membuat masyarakat menjadi khawatir jika ingin memberikan masukan dan kritikan kepada pemerintah. Selain itu, UU ITE dianggap belum memberikan jaminan atas kebebasan berpendapat masyarakat dalam memberikan kritikan kepada pemerintah melalui media sosial. Karena di dalam UU ITE tersebut masih terdapat pasal-pasal karet yang menimbulkan multitafsir berbagai kalangan. Itulah hubungan antara masyarakat dalam memberikan kritikan kepada pemerintah dengan UU ITE.

Dengan demikian, maka diperlukan revisi terhadap UU ITE tersebut. Tujuannya agar masyarakat mendapatkan jaminan perlindungan dan

terbebas dari sanksi pidana ketika memberikan masukan dan kritikan kepada pemerintah sehingga dapat mewujudkan negara yang demokrasi.

\section{Buku}

\section{DAFTAR PUSTAKA}

Bisri, Ilhami. (2005). Sistem Hukum Indonesia, Prinsip-prinsip dan Implementasi Hukum Indonesia, Jakarta: Grafindo Persada.

R. Soesilo. (1991). Kitab Undang-Undang Hukum Pidana (KUHP) serta Komentar-Komentarnya Lengkap Pasal Demi Pasal, Bogor: Politeia.

Sugiyono, (2008). Metode Penelitian Kunatitatif Kualitatif dan R\&D. Bandung Alfabeta.

Yulies Tiena Masriani,. (2008). Pengantar Hukum Indonesia, Jakarta: Sinar Grafika.

\section{Regulasi}

Undang-Undang Nomor 14 Tahun 2008 tentang Keterbukaan Informasi Publik.

Undang-Undang Nomor 11 Tahun 2008 tentang Undang-Undang Informasi dan Transaksi Elektronik.

Undang-Undang Nomor 19 Tahun 2016 tentang Perubahan Atas Undang-Undang Nomor 11 Tahun 2008 tentang Informasi dan Transaksi Elektronik.

\section{Jurnal}

John W, Johnson. (2001). "Peran Media Bebas". Office of International Information Program U.S Department of State No. 7 Maret 2001. 
Hardijan, Rusli. (2006). "Metode Penelitian Hukum Normatif', Law Review, Vol. 5, No. 3, 2006.

Hasibuan, Albert. (2008). "Politik Hak Asasi Manusia dan UUD 1945", Law Review, Vol. 8, No. 1, 2008.

Herlambang, Perdana. (2009). "Kebebasan Berekspresi, Penelusuran dalam Konstitusi Indonesia", Jurnal Konstitusi, Vol. 6, No. 1, 2009.

Priliantini, Anjang dan Damayanti. (2018). "Peran Media Sosial "Facebook" dalam Membentuk Solidaritas Kelompok pada Aksi 411 dan 212", Jurnal Komunikasi, Media dan Informatika, Vol. 7, No. 1, 2018.

Sartini. (2008). “Etika Kebebasan Beragama”. Jurnal Filsafat. Vol 18 No 3, 2008.

Watie, Errika Dwi Setya. (2012). "Periklanan dalam Media Baru (Advertising In The New Media)". Jurnal The Messenger, Vol. 4, No. 1, 2012.

\section{Artikel}

Khalifa, Thea Mutiara. (2018). Undang-Undang Informasi dan Transaksi Elektronik: Bentuk. Perlindungan atau Alat Kepentingan Pemerintah? Dalam https://lk2fhui.law.ui.ac.id/undang-undang-informasi-dan-transaksi-elektronikbentuk-perlindungan-atau-alat-kepentingan-pemerintah/, (Diakses 9 Maret 2021 pukul 19.18 WIB).

Ngazis Amal Nur. (2012). Prita Bebas, Kritik di Internet Tak Boleh Gegabah. Dalam https://www.viva.co.id/digital/digilife/352490-prita-bebas-kritik-di-internet-takboleh-gegabah, (Diakses pada tanggal 25 Februari 2021 pukul 10.30 WIB).

Saptoyo, Rosy Dewi Arianti. (2021). Jokowi Minta Masyarakat Aktif Beri Kritik, Warganet: Lalu Kena UU ITE. Dalam https://www.kompas.com/tren/read/2021/02/09/160000565/jokowi-mintamasyarakat-aktif-beri-kritik-warganet-lalu-kena-uu-ite?page=all, (Diakses pada tanggal 27 Februari 2021 pukul 12.12 WIB). 